Despite advances in technology, agriculture remains laborintensive. Thousands of workers are still required for tasks such as picking and pruning.
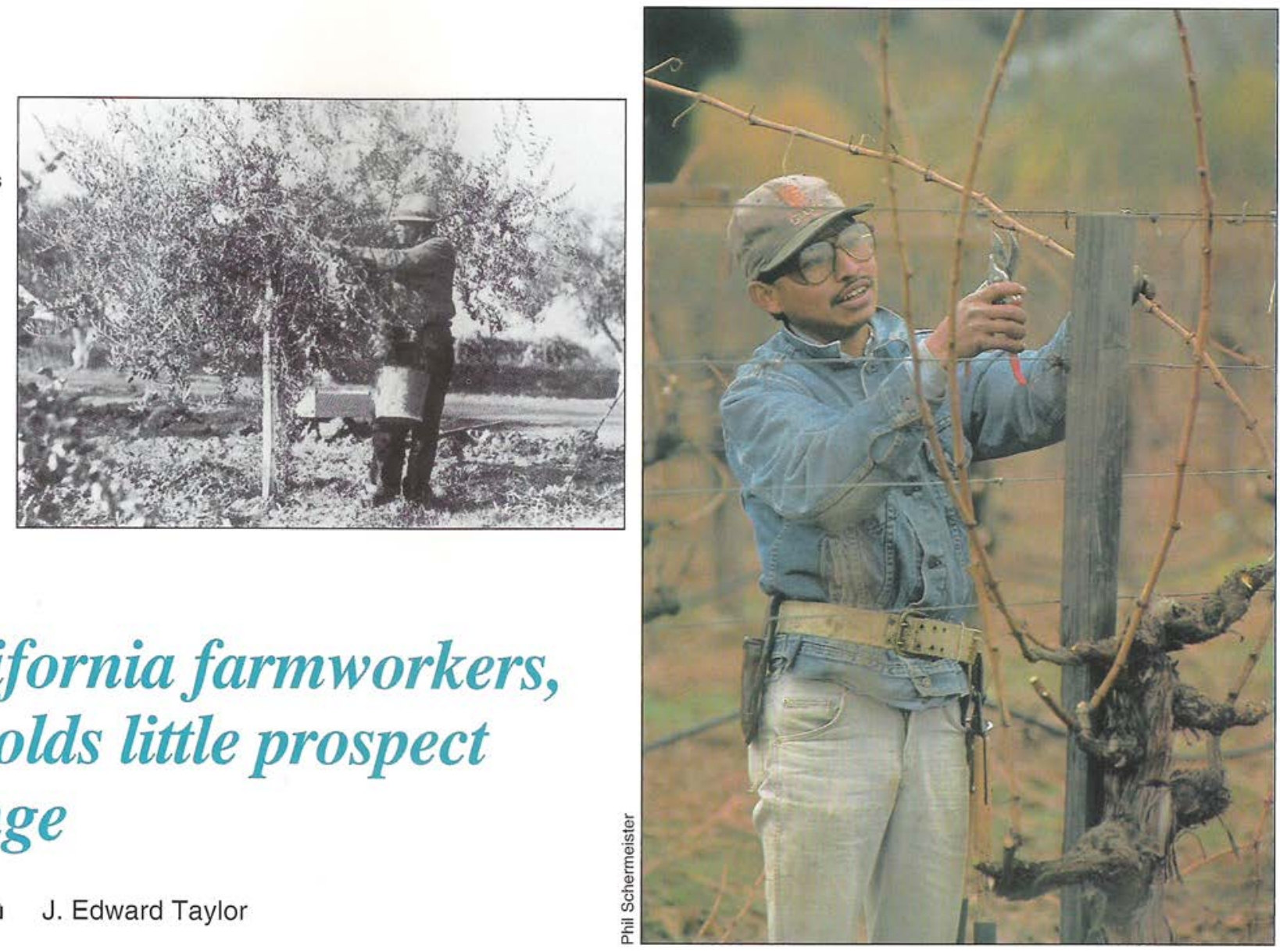

\title{
For California farmworkers, future holds little prospect for change
}

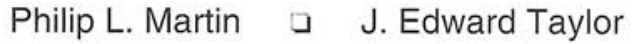

\begin{abstract}
Agriculture is a major employer in California. Some 800,000 to 900,000 people work for wages at some time during a typical year on California farms. Only about half of those work year-round so that farmworkers represent just $3 \%$ of California's average $14 \mathrm{mil}-$ lion wage and salary workers. Most farmworkers in California are seasonally employed on one farm for less than 6 months each year, and earn a quarter of the average factory worker's annual salary. The vast majority are Hispanic immigrants. During the next quarter century, these trends are likely to continue, with the farm labor market becoming increasingly isolated from the mainstream. An alternative scenario is that strong unions and government regulations could transform farm work into an occupation that can provide a career and support a family. Immigration policy will play a critical role in determining the characteristics of California farmworkers in the 21st century.
\end{abstract}

$\mathrm{M}$ ost major farm labor debates at the dawn of the 21st century involve arguments about the proper role of government in the farm labor market. How should trade and research policies influence farmer decisions on what crops to grow and how to harvest them? How easy should it be for farmers to employ foreigners as guest workers? What labor and immigration laws should apply to the farm labor market, and how active should governments be in enforcing these laws?

Current debates about the farm labor market can be framed by two extremes. One scenario imagines that hired farmworkers will increasingly be recently arrived immigrants, so that the farm labor market will be further isolated from other U.S. labor markets. Under this scenario, the seasonal workers of 2020 are being born today in Mexico and Central America. The other extreme imagines unions or government regulation making farm work an occupation that can provide a career and support a family. The actions of farmers, workers and government will determine where the reality is likely to fall between these extremes.
This paper surveys the farm labor market at the beginning of the 21st century and outlines its likely evolution. The number and characteristics of farmworkers played a major role in shaping 20th-century agriculture and the farm labor market, and the farm labor supply is likely to continue to do so in the 21st century. At the beginning of the 20th century, farmers worried about whether Chinese and Japanese farmworkers would continue to be available; at the end of the 20th century, farmers worry about the future availability of Mexican farmworkers.

During a typical year, the 35,000 farm employers in California, including crop growers, livestock farmers, custom harvesters and farm labor contractors (FLCs), hire 800,000 to 900,000 individuals. Most farm employers are native-born, non-Hispanic whites, while most farmworkers are Hispanic immigrants.

Farmworkers' average hourly earnings are about half of average manufacturing wages, $\$ 6$ to $\$ 8$ versus $\$ 12$ to $\$ 14$ per hour. The average hourly earnings reported by the U.S. Department of Agriculture in Farm Labor pub- 
lication include the earnings of supervisors, which raises average hourly earning figures (USDA 1999). In 1999, for example, average hourly earnings for all hired workers in California were $\$ 7.88$. However, average hourly earnings for field workers were lower: $\$ 7.18$. Farmworkers average about 1,000 hours of work per year, about half as many as manufacturing workers. As a result,

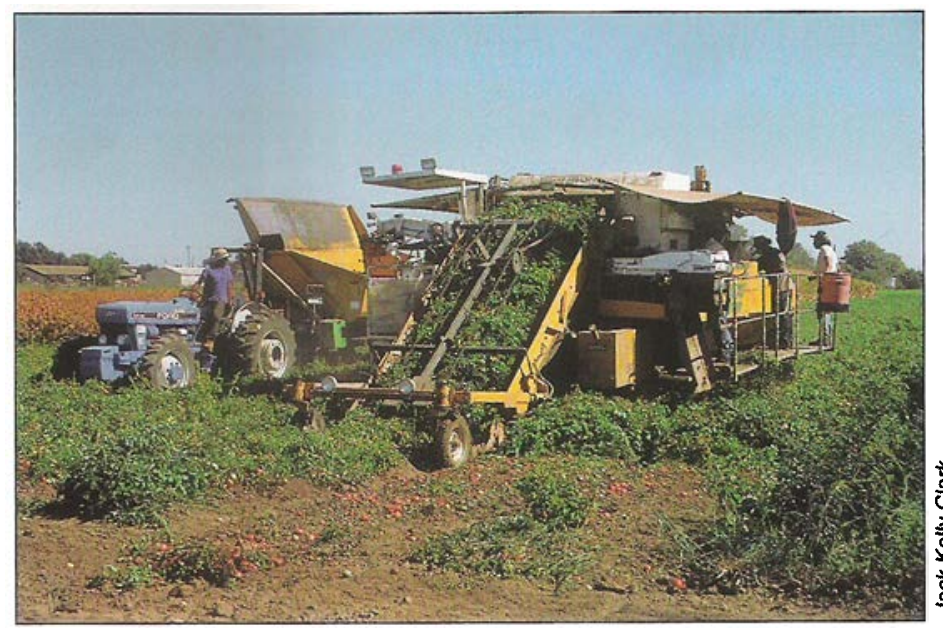

California farming is often compared to manufacturing, with open-air enterprises converting raw materials into finished products.

farmworkers in California have annual earnings that are one-fourth of the $\$ 24,000$ to $\$ 28,000$ average of factory workers.

\section{Farm labor market characteristics}

Four characteristics distinguish the farm labor market in California:

- The farm labor market is dominated by specialized enterprises with highly seasonal labor demands - peak employment can be 20 to 30 times greater than trough employment.

- Since 1960, labor-saving technologies have not reduced the overall demand for low-skill farmworkers. Instead, increased production of labor-intensive crops and the shift of some nonfarm packing work to the fields (for example, field packing) increased the average monthly employment of farmworkers in the 1990s.

- Most farmworkers are immigrants, and virtually all new entrants to the farm work force were born abroad. U.S.-born workers have almost entirely disappeared from the farm labor market.

- Farmworker earnings are among the lowest of any segment of the U.S. work force, reflecting relatively low wages and less than full-time employment. Relatively few farmworkers receive fringe benefits such as health insurance so the farm-nonfarm gap in total compensation (earnings plus fringe benefits) widened in the 1980s and 1990s.
Farming in California is often compared to manufacturing. Most farmworkers in California are employed in open-air enterprises that turn raw materials into finished products. A "farm factory" brings together people, land, water and machines to transform seeds into crops. Because the agricultural production process is biological, farm factories face risks that do not arise in manufacturing production processes governed by engineering relationships.

California agriculture is dominated by specialized enterprises that often hire hundreds of workers for a 3-week harvest. Unlike the typical Midwestern family farmer, who does most of his own farm's work, the managers responsible for California's labor-intensive crops rarely hand-harvest themselves. A familiar adage captures many of the differences between California agriculture and Midwestern family farms: California agriculture is a business, not a way of life.

California fruits and vegetables do not ripen uniformly, so the peak demand for labor shifts around the state in a manner that mirrors harvest activities (see box, p. 22). Harvest activity occurs year-round, beginning with the winter vegetable harvest in Southern California and the winter citrus harvest in the San Joaquin Valley and ending with late olive and kiwi harvests in October.

In late fall and early winter, some workers migrate to Southern California and Arizona for the winter vegetable harvest, and others return to
Mexico, but most remain in the areas where they did farm work, jobless and waiting for a new season to start.

Workers willing to follow the ripening crops can find 8 to 10 months of harvest work each year. Howis ever, relatively few workers follow the ripening crops in California. A 1965 survey found that $30 \%$ of the workers migrated from one of California's farming regions to another (California Assembly 1969), and a 1981 survey of Tulare County farmworkers found that only $20 \%$ had to establish a temporary residence away from their usual home because a farm job took them beyond commuting distance (Mines and Kearney 1982). The National Agricultural Workers Survey, conducted annually, reported that $20 \%$ to $40 \%$ of California crop workers interviewed would be willing to or had traveled beyond daily commuting distance from their homes to do farm work (USDOL 1998, Gabbard et al. 1994).

The number of farm jobs in California has been remarkably stable since the 1960s, and it rose in the 1990s (fig. 1). The loss of jobs due to picking a crop by machine rather than by hand in many commodities has been offset by the growth of jobs in other farm commodities and the substitution of hired workers for family workers on many farms. During the 1960s, when the processing-tomato harvest was mechanized, it was widely expected that most crops grown in California would be harvested mechanically by 1975. This did not happen, largely because workers were generally available and because of the costs involved in adapting plants and machines for hand-harvesting some perishable commodities.

\section{Labor in the 1990s}

Most California farmworkers are Hispanic immigrants. The National 
Agricultural Workers Survey interviewed 1,885 crop workers employed in nine California counties between 1995 and 1997, and found that $95 \%$ were foreign-born, including $91 \%$ who were born in Mexico (fig. 2). About $53 \%$ of those interviewed had been in the United States for less than 5 years, and $26 \%$ for less than 2 years. About $48 \%$ were legal immigrants and $42 \%$ were unauthorized (USDOL 1998).

Most farmworkers are young men with families. In 1995 through 1997, about $82 \%$ of California crop workers were men. The median age of farmworkers was $30,31 \%$ were under 24 , and $63 \%$ were under 34 . About $61 \%$ of crop workers were married, and most married workers had families, with an average of three children each. About $60 \%$ of farmworkers in the mid- $1990 \mathrm{~s}$ had their families living with them while they did farm work in California; $40 \%$ left their families outside the United States. Two-thirds of the workers interviewed had less than 8 years of education, which they usually acquired abroad. Their median years of schooling is 6 (USDOL 1998).

California farmworkers averaged 23 weeks of farm work a year in the mid1990s, 3 weeks of nonfarm work, and 26 weeks without farm work. In most cases, time not working is spent outside the United States. Most of the workers interviewed $(91 \%)$ were employed in fruits and vegetables. Of the jobs performed by sample workers in the previous 12 months, about $70 \%$ were pruning, irrigating and other nonharvest operations, and $31 \%$ were harvesting. Hours of work averaged 42 a week, and average hourly earnings were $\$ 5.69$. Most interviewed workers had low incomes; $55 \%$ earned less than \$7,500 in 1996 (USDOL 1998).

\section{A century of farm work}

These characteristics of farmworkers are not new. Farmworkers have generally been newcomers to the state with few nonfarm job options because they lacked the language, skills and contacts to move out of the farm labor market. California farm-labor history is the story of waves of newcomers entering the state to do farm work, and then returning to their country of origin or moving into nonfarm jobs. Farmworker's children who are educated in California generally refuse to follow their parents into the fields, so that most entry farmworkers have been raised outside the state (Martin 1996).

The state's growers have had a keen interest in U.S. immigration policy since labor-intensive fruit and vegetable farming developed in the $1880 \mathrm{~s}$. Farmers feared that they would have to slow the planting of trees and vines in the 1880 s, after the federal government ended Chinese immigration in 1883. However, labor became available from Japan, and plantings of labor-intensive crops tripled in the 1890s. Worries about unskilled immigrants in cities led the United States in 1917 to exclude immigrants over 16 who could not read in any language. California farmers asked the U.S. government to exempt Mexicans coming to work on farms and railroads, and Mexicans soon dominated the farm work force in many areas.

Mexicans stopped migrating to the United States to do farm work in the 1930s, and many already in California were forced to return to Mexico during the Depression. After 1935, small farmers from the Midwest and South began arriving in California, hoping to begin as hired-hand farmworkers and work their way up the agricultural job ladder to become farmers in their own right. Most did not, and the conditions under which some lived inspired an outpouring of farm-labor literature, including John Steinbeck's The Grapes of Wrath in 1940.

By 1942, many farmworkers were drawn into the armed forces and industry, and growers fearing labor shortages persuaded the U.S. and Mexican governments to sign the first of what would become 22 years of bracero agreements that permitted Mexicans to enter the United States to work on farms. As rising incomes and

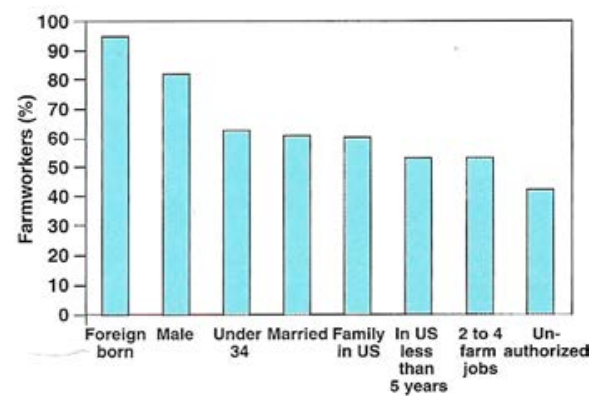

Fig. 2. Characteristics of California farmworkers, 1992-1997. Source: National Agricultural Workers Survey.

population growth increased the demand for fruits and vegetables, and transportation improvements enabled California growers to produce commodities that could travel to the East Coast, the availability of bracero workers facilitated the expansion of agriculture. When the bracero program ended in 1964, many growers feared that lack of labor would force them to mechanize or stop growing labor-intensive crops.

UC received special funding to accelerate labor-saving research by redesigning plants and machines, as with processing tomatoes. Meanwhile, the absence of bracero workers enabled Cesar Chavez and the United Farm Workers (UFW) union to obtain a $40 \%$, 1 -year wage increases from some grape growers in 1966 . There were predictions that the day of the unskilled farmworker was fast coming to a close, prompting the federal government to launch a series of programs that helped farmworkers, especially migrants and their children, to "escape" from farm work (Martin 1998). 


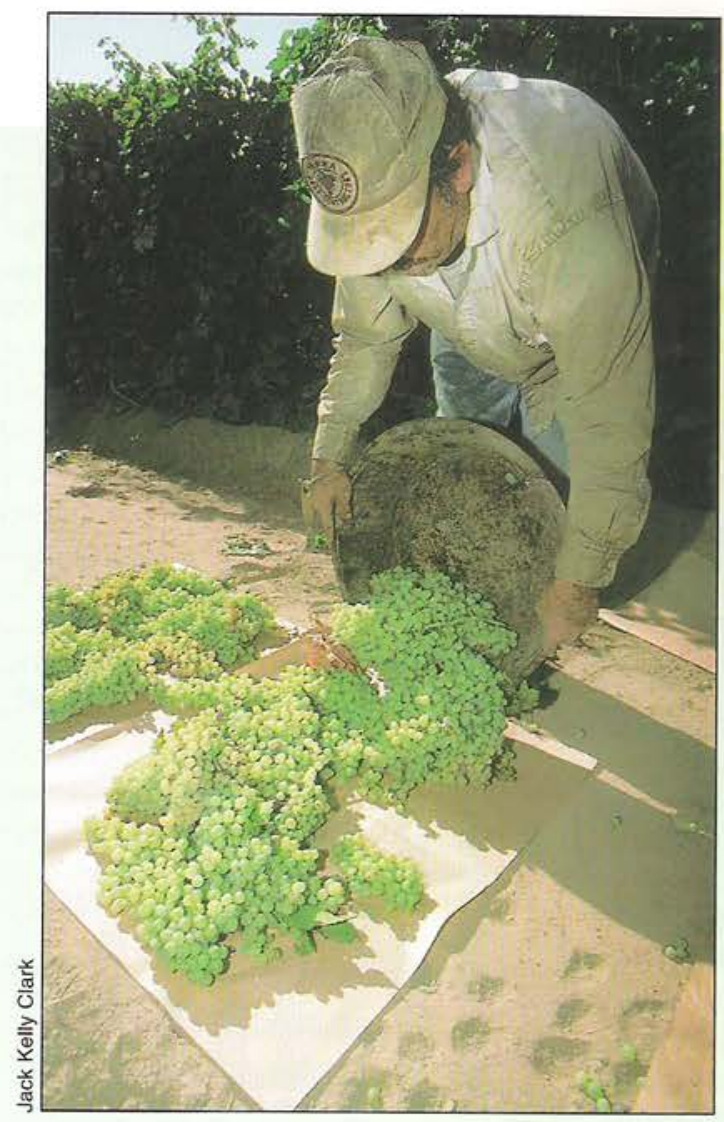

\section{A year in the fields}

Farm work changes throughout the year in California. Seasonal work includes the following activities:

January/February. Branches and vines are pruned to promote the growth of larger fruit. For peaches, pruning accounts for $10 \%$ to $20 \%$ of the seasonal labor, but because it occurs over several months, fewer workers are involved than in harvesting. During the winter months, employment on farms is only half of its peak September levels.

March/April. Harvesting moves northward into the coastal plains, with workers harvesting lemons and oranges in Southern California, working flower and nursery crops, and thinning and weeding vegetable crops in the Salinas area.

May. Picking of strawberries and vegetables begins on the
Up to 50,000 workers are hired in late summer and early fall to harvest 300,000 acres of California raisin grapes.

June. A statewide minipeak in the demand for labor occurs in June. Tree fruits such as apricots, peaches, plums and nectarines must be thinned in the San Joaquin Valley, with workers removing some fruit buds to provide larger harvested fruit. Some tree fruits, such as cherries, are ready to be harvested in late spring, as are table grapes and vegetables in the Coachella Valley and Southern California produce.

July/August. During the summer months, vegetables continue to be harvested in the coastal valleys. In the Central Valley, up to 150,000 farmworkers harvest tree fruits as well as cantaloupes, melons, tomatoes and Valencia oranges. Thousands of farmworkers are also hired to irrigate crops and to weed field crops such as cotton.

September. Farmworker employment reaches its peak with a series of short and labor-intensive harvests, including the 40,000 to 50,000 workers needed to harvest 300,000 acres of raisin grapes. Peach and melon employers worry about whether "their workers" will remain to finish the harvest, while raisin growers worry that too few workers will show up before rain threatens to ruin the drying grapes.

October. Only a few late harvests remain, including olives and kiwi fruit. Most of the food processing and packing workers are laid off, and these nonfarm operations shut down for the year.

November/December: Some harvesting of winter vegetables takes place in Southern California and Arizona, but most workers are idle

\section{Farm wages/prices index}

Predictions of a mechanized agriculture proved premature. Americans increased their consumption of fruits and vegetables in the 1970s and 1980s, and Mexican workers continued to enter the state to do farm work legally and illegally. By the early 1980 s, when the United States discussed imposing sanctions or fines on employers who knowingly hired unauthorized workers, farmers feared that immigration reforms would lead to labor shortages. The Immigration Reform and Control Act (IRCA) of 1986, which was intended to give agriculture a legal labor force and set in motion gradual wage increases, instead led to a new wave of authorized and unauthorized immigrant farmworkers (Martin et al. 1995).

IRCA created two legalization programs: a general program that granted legal status to 1.7 million illegal aliens who had resided continuously in the United States since Jan. 1, 1982, and the Special Agricultural Worker or SAW program, which granted legal status to 1.1 million illegal aliens who did at least 90 days of farm work in 1985-86; half of the SAWs legalized were in California. In addition, IRCA gave farmers two guest-worker programs under which they could obtain legal farmworkers if there were farm labor shortages.

According to the federal Commission on Agricultural Workers, appointed by the president and Congress to review the effects of immigration reforms on U.S. agriculture, the SAW program legalized about a million young Mexican men, equivalent to one-sixth of the adult men in rural Mexico in the mid-1980s (CAW 1992). The expectation was that these now legal immigrant farmworkers would continue to leave their families in Mexico, where the cost of living was lower, and commute seasonally between homes in Mexico and farm jobs in the United States. The fact that legal SAW farmworkers could take nonfarm jobs, it was thought, would force U.S. growers to increase wages and improve working conditions.

Both assumptions proved to be false. First, many of those legalized under the SAW program moved their 


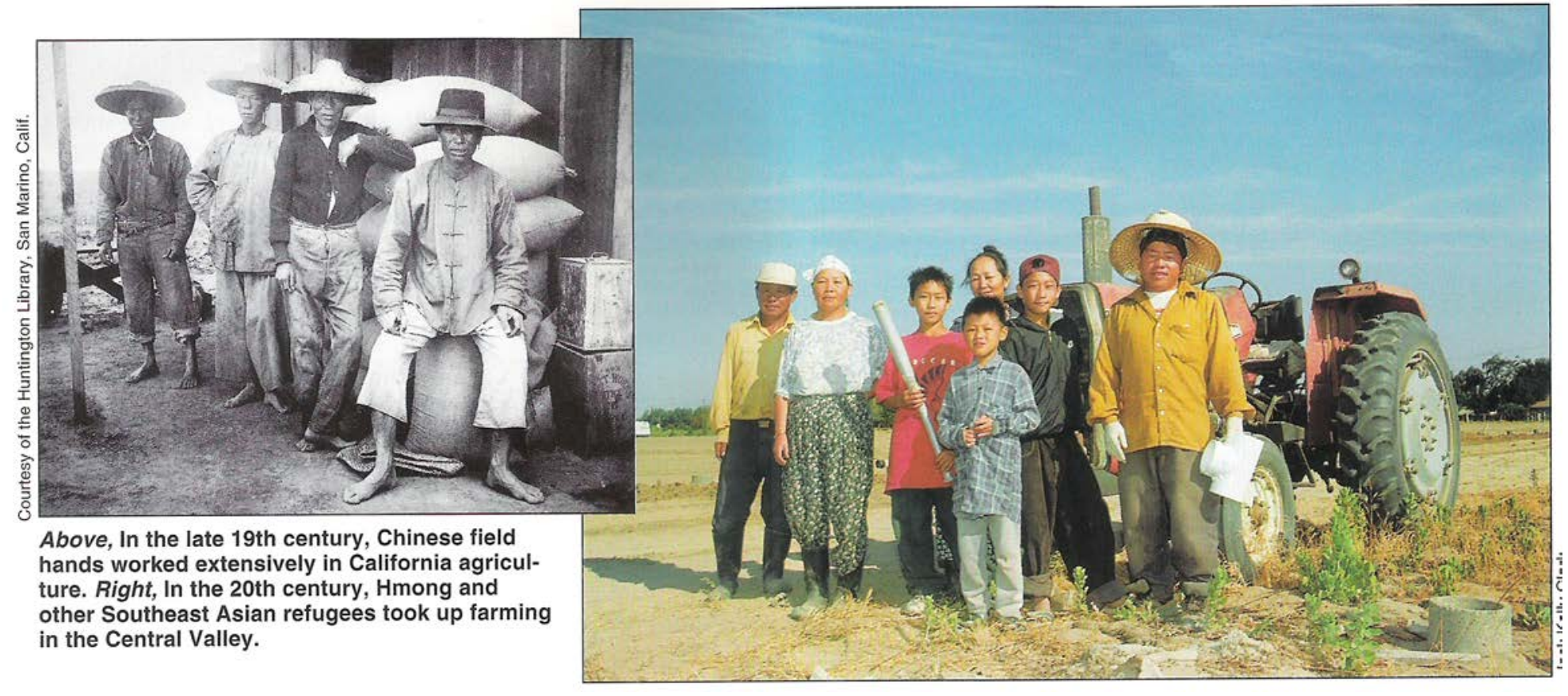

families to the United States in the early $1990 \mathrm{~s}$. Second, farm wages and working conditions did not improve as expected because unauthorized workers continued to be readily available. Third, the farm labor market changed. As the percentage of unauthorized workers rose in the 1990s, the risks that an employer would be sanctioned for labor-law and immigration violations also increased. Farm labor contractors (FLCs) emerged as risk buffers between farmers and farmworkers. FLCs proved willing to assemble crews of workers and to assume the payroll and other risks associated with farm employment.

Farm labor contractors. Every year, hundreds of thousands of farmworkers are assembled into crews of 20 to 40 for jobs that typically last for a few weeks on a particular farm (Taylor and Thilmany 1993; Rural Migration News 1998). FLCs and foremen or crew bosses have been described as the glue that holds the farm labor market together, because they serve as intermediaries between workers and farmers. In some cases, foremen or crew bosses are employed year-round by the farmer, and they recruit seasonal workers as needed. (In the scramble for workers, vans driven by raiteros act as a private transportation system in agricultural areas, ferrying workers between the farmworker sections of cities and fields.)

Each of the 1,300 FLCs registered in California in 1995 was required to ob- tain a license that costs $\$ 350$ a year, post a $\$ 10,000$ bond and pass a test on labor and pesticide laws (Rural Migration News 1999). Many FLCs are accused of taking advantage of vulnerable workers, levying unlawful charges for tools and rides to work, or not paying workers promised wages. Federal, state and local governments have erected an elaborate regulatory framework that attempts to encourage contractors and foremen to learn about and abide by labor and immigration laws, but there is considerable doubt about the efficacy of these laws. Between 1992 and 1995, a coordinated federal-state enforcement effort, the Targeted Industries Partnership Program (TIPP), found major violations committed by $90 \%$ of California FLCs inspected. A TIPP inspection of 23 FLCs with crews pruning vineyards in January and February of 1998 found that $52 \%$ of the FLCs were not paying their workers the minimum wage of $\$ 5.75$ an hour (Rural Migration News 1999).

Unions. Unions have been active in California agriculture throughout the 20 th century, but most have proved to be short-lived. For example, the Industrial Workers of the World was active before World War II, the Cannery and Agricultural Workers Industrial Union was active in the early 1930 s and the UFW has been active since the mid1960s.

In 1975, California became the first major agricultural state to enact a farm-labor-relations law under which farmworkers could choose, under state oversight, whether they wanted to be represented by a union. If farmworkers voted for union representation in state-supervised elections, farm employers were legally obliged to bargain with the union the workers selected. The California Agricultural Labor Relations Board (ALRB) has supervised 1,600 elections on farms and certified 10 unions to represent farmworkers on about 800 farms since 1975 (Martin 1996). However, there were fewer than 300 union contracts in 1999 , and about 200 of the contracts cover fewer than 10 workers each on the state's dairies.

The best-known farmworker union today is the UFW, which had a peak of

A farmer from 1900
would be baffled by laser
land-leveling, drip
irrigation, vacuum cooling
and the widespread use
of computers, but would
be very familiar with the
use of bilingual contrac-
tors and crew bosses to
assemble immigrant
farmworkers to perform
seasonal harvesting tasks.




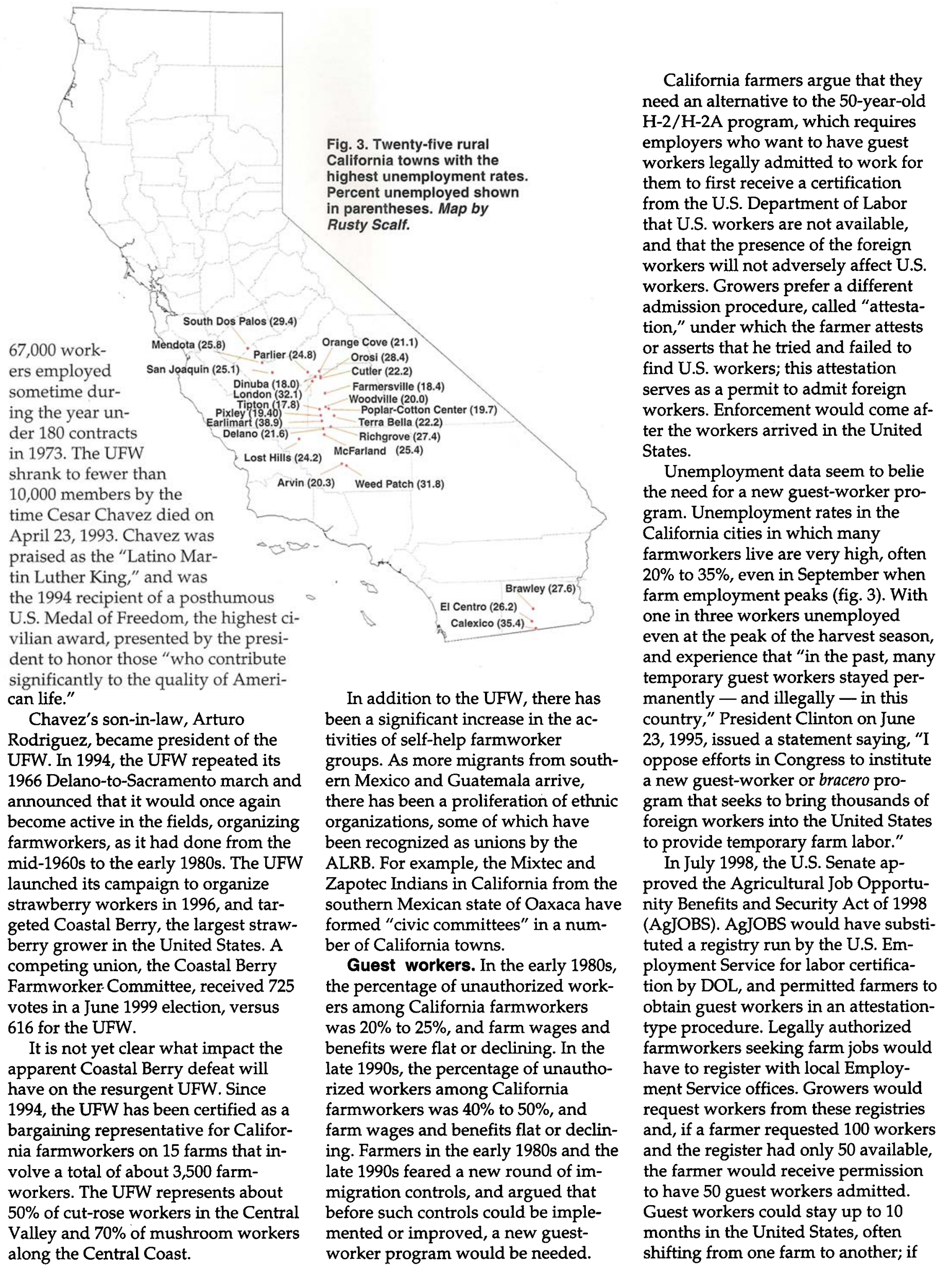


they did a certain number of days of farm work each year for 5 years - the suggestions are 90 to 150 days - they could earn an immigrant status under bills pending in Congress.

The current H-2A certification program is growing slowly. In 1997, DOL certified the need for $23,352 \mathrm{H}-2 \mathrm{~A}$ foreign farmworkers, up from 17,557 in 1996 and 12,173 in 1994. In 1997, 62\% of the jobs certified were in Southeastern tobacco, another $18 \%$ were in Northeastern apples and $7 \%$ were in Western sheep herding, including California. Many of the H-2A sheepherders in California are from Peru, Mexico and China. Most are paid $\$ 700$ to $\$ 750$ a month and provided with a trailer and food. They usually receive 2 weeks paid vacation each year, and group health and worker's compensation insurance. Each shepherd is usually assigned about 800 sheep.

\section{Future in focus: \\ No major changes expected}

One remarkable feature of the California farm labor market is how little change there has been in basic parameters over the past century - using bilingual middlemen to hire crews of seasonal workers, and worrying about whether enough workers will be available next year. A farmer from 1900 would be baffled by laser landleveling, drip irrigation, vacuum cooling and the widespread use of computers, but would be very familiar with the use of bilingual contractors and crew bosses to assemble immigrant farmworkers to perform seasonal harvesting tasks.

The CAW final report (1992) called for an end to "agricultural exceptionalism," or special immigration and labor laws for agriculture; a renewed effort to reduce illegal immigration; and better enforcement of the labor laws that protect farmworkers. Six of the $11 \mathrm{CAW}$ commissioners were from California. The commission surprised many observers by not recommending a new guest-worker program, instead calling for additional federal and state services for farmworkers, including more housing and services to assure equal opportunities for farmworker children.
How these workers and their children fare in their new communities will depend on government policy decisions, especially critical while the economy is strong.

Immigration policy is the wild card in shaping the future of the California farm labor market. If new entrants to the farm work force continue to be immigrants from abroad, then U.S. immigration policy will determine the number and characteristics of farm workers in the 21st century. Farmworker numbers and characteristics, in turn, will determine pressures for wage increases and benefit improvements. Immigration policy, a federal government decision, is the key variable affecting how immigrant workers and their children are likely to fare in California's rural and agricultural areas.

P.L. Martin is Professor and J.E. Taylor is Professor, Department of Agricultural and Resource Economics, UC Davis.

\section{References}

California Assembly Committee on Agriculture. 1969. The California farm work force: A profile. Sacramento. April. 146 p.

[CAW] Commission on Agricultural Workers. 1992. Final Report. Washington, DC: Government Printing Office. 188 p.

Gabbard S, Mines R, Boccalandro B. 1994. Migrant farmworkers: Pursuing security in an unstable labor market. Washington, DC: US Department of Labor, ASP Research Report 5 , May. $34 \mathrm{p}$.

Martin P. 1998. The endless debate: Immigration and $U S$ agriculture. In: Duignan $P$, Gann L (eds.). The Debate in the United States over Immigration. Stanford, CA: Hoover Institution. p 79-101.

Martin P. 1996. Promises to Keep: Collective Bargaining in California Agriculture.

Ames, IA: lowa State University Press. 416 p. Martin P, Huffman W, Emerson R, et al. 1995. Immigration reform and US agriculture. Berkeley, CA: Division of Agriculture and Natural Resources, Publication 3358.580 p. Mines R, Kearney M. 1982. The health of Tulare County farmworkers. Mimeo April. $46 \mathrm{p}$.

Rural Migration News. 1999. California: Enforcement, Workers Comp. 5(1), January. http://migration.ucdavis.edu.

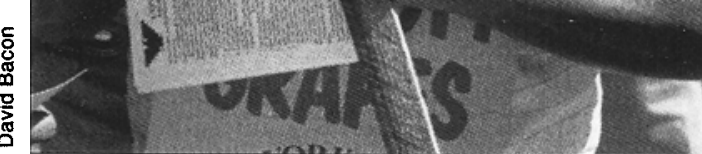

Top, During the mid-1940s, prospective braceros lined up for farm work in the United States at a Mexico City soccer stadium. Below, Cesar Chavez, who died in 1993, was a powerful advocate for the rights of farmworkers.

Rural Migration News. 1998. Enforcement: Children, FLCs, MSPA. 4(3), July. http:// migration.ucdavis.edu.

Taylor J, Thilmany D. 1993. Worker turnover, farm labor contractors and IRCA's impact on the California farm labor market. Am $\mathrm{J} \mathrm{Ag}$ Econ 75(2):350-60.

[USDA] US Department of Agriculture. National Agricultural Statistics Service. 19751999. Quarterly. Farm Labor. http:// usda.mannlib.cornell.edu/reports/nassr/other/ pfl-bb.

[USDOL] US Department of Labor. Office of the Assistant Secretary for Policy. 19911998. National Agricultural Workers Survey (NAWS). Annual. www.dol.gov/dol/asp/public/programs/agworker/naws.htm. 